\title{
Wybrane aspekty spożycia wołowiny w rejonie o niekorzystnych wskaźnikach makroekonomicznych
}

\section{Wstęp}

Dostępne dane statystyczne wskazują, że obecnie najczęściej spożywanym rodzajem mięsa w Polsce jest wieprzowina, stanowiąca 55-53\% spożywanego mięsa w latach 2005-2015 (39,0-41,7 kg/osobę/rok). Konsumpcja mięsa wieprzowego w Polsce, na tle pozostałych krajów Unii Europejskiej, kształtuje się na poziomie zbliżonym do przeciętnego. Kolejnym gatunkiem mięsa jest mięso drobiowe, którego poziom spożycia w latach 2005-2015 stale wzrastał z 23,4 do $28,3 \mathrm{~kg} /$ osobę/rok. Przeciwny trend zaobserwować można w przypadku mięsa wołowego, którego konsumpcja systematycznie maleje - w latach 2005-2015 zanotowano spadek z 3,9 do 1,6 kg/osobę/rok [GUS 2010, 2016].

Głównym czynnikiem wzrostu spożycia mięsa ogółem jest obecnie globalny rozwój gospodarczy oraz wzrost liczby ludności na świecie. Przewidywane zwiększenie liczby ludności świata do ponad 9 miliardów w 2050 roku spowoduje dalszy wzrost zapotrzebowania na mięso i jego przetwory, a globalny popyt na mięso i przetwory mięsne wzrośnie do 2030 roku o 85\% [Evans 2009]. Coraz większe znaczenie w globalnej konsumpcji mięsa będą odgrywać rynki azjatyckie - np. w Indiach zaobserwowano pojawienie się nowej klasy średniej, tzw. non-veg, która odrzuca na rzecz nowych wzorców kulturowych popularny w tym regionie świata wegetarianizm [Meat Atlas... 2014].

Jakkolwiek twierdzi się, że wraz ze wzrostem zamożności zarówno ogółu społeczeństwa, jak i poszczególnych gospodarstw domowych wzrasta popyt na produkty pochodzenia zwierzęcego, a w tym zwłaszcza mięso i wędliny, to warto zwrócić uwagę na zaskakujące niekiedy tendencje w spożyciu wołowi- 
ny, a więc odnotowywany wyższy, niż można by się spodziewać, poziom jej konsumpcji w regionach o relatywnie niekorzystnych wskaźnikach makroekonomicznych, które powinny raczej wyzwalać skłonności do redukcji spożycia droższych gatunków mięsa na rzecz jego tańszych substytutów [Gutkowska i Ozimek 2008, Gutkowska i in. 2012]. Sytuacja taka występuje w województwie świętokrzyskim, gdzie pomimo istnienia relatywnie niekorzystnych wskaźników makroekonomicznych, obserwuje się stosunkowo wysoki poziom spożycia wołowiny, podobny jak w gospodarstwach domowych w województwach o znacznie korzystniejszym ich wymiarze (np. mazowieckim, śląskim). Fakt ten skłania do rozpoznania przyczyn zaskakująco wyższego, niż można by się spodziewać, poziomu spożycia wołowiny $\mathrm{w}$ gospodarstwach domowych w województwie świętokrzyskim, co korespondowało też z założeniami jednego z zadań badawczych w projekcie „ProOptiBeef”, , w ramach którego przeprowadzono badania, których wycinek prezentowany jest w niniejszym artykule.

\section{Cel, metody i materiał badawczy}

Celem podjętych badań było m.in. określenie specyfiki zachowań konsumenckich mieszkańców województwa świętokrzyskiego wobec wołowiny, zarówno w odniesieniu do częstotliwości, wielkości i powodów jej spożywania, jak i innych aspektów zachowań żywieniowych konsumentów zamieszkujących ten region kraju.

Przyjęto hipotezę, że socjodemograficzna i ekonomiczna charakterystyka gospodarstw domowych z województwa świętokrzyskiego, charakteryzujących się najwyższym i najniższym poziomem spożycia wołowiny, wykazuje podobne cechy jak w ogólnej populacji gospodarstw domowych w Polsce.

Realizacja celu pracy oraz weryfikacja postawionej hipotezy została dokonana poprzez analizę danych ze źródeł wtórnych i pierwotnych. Wtórnymi źródłami były informacje pochodzące z polskich i zagranicznych publikacji naukowych oraz pozyskane w ramach analiz indywidualnych danych budżetów gospodarstw domowych. Pierwotne źródła stanowiły wyniki badań ankietowych przeprowadzonych wśród mieszkańców województwa świętokrzyskiego w okresie od lutego 2013 do września 2014 roku. Zastosowany w badaniach autorski kwestionariusz zawierał 49 pytań, wśród których było 45 pytań zamkniętych

\footnotetext{
${ }^{1}$ Badania zrealizowano $\mathrm{w}$ ramach projektu pt. „Optymalizacja produkcji wołowiny w Polsce zgodnie ze strategią od »widelca do zagrody «”, współfinansowanego ze środków Europejskiego Funduszu Rozwoju Regionalnego w ramach Programu Operacyjnego Innowacyjna Gospodarka 2007-2013 (umowa nr UDA-POIG.01.03.01-00-204/09); kierownik naukowy zadania nr 1 „Analiza popytu na mięso wołowe w Polsce" - prof. dr hab. Krystyna Gutkowska.
} 
i 4 pytania otwarte. Pytania zawarte w kwestionariuszu miały na celu ocenę m.in. poziomu spożycia wołowiny oraz postaw i zachowań konsumentów na rynku mięsa wołowego. Badania przeprowadzono wśród 1206 konsumentów mieszkających w województwie świętokrzyskim. Po analizie kompletności wypełnionych kwestionariuszy do ostatecznych analiz statystycznych zakwalifikowano kwestionariusze pochodzące od 1004 osób. W celu określenia istotnych statystycznie różnic między zmiennymi zastosowano statystykę $\chi^{2}$ (poziom istotności $\mathrm{p}<0,05)$ oraz wykonano analizę częstości.

\section{Zmiany w zachowaniach polskich konsumentów na rynku mięsa ze szczególnym uwzględnieniem rynku wołowiny}

Perenc [2010] zauważa, że do zmian w ilości i jakości spożywanej żywności oraz do zmian zachowań konsumpcyjnych na rynku żywności w Polsce przyczyniły się przeobrażenia społeczno-gospodarcze, które rozpoczęły się od początkowych lat transformacji, a więc od 1989 roku. Zmiany nastąpiły zarówno w zwyczajach zakupowych konsumentów, jak i ich wymaganiach oraz preferencjach [Światowy 2006]. Podobne zmiany zauważono również u konsumentów mięsa i produktów mięsnych.

Silnie oddziałującymi determinantami na zachowania polskich konsumentów wołowiny są czynniki ekonomiczne. Gutkowska i inni [2012] w swoich badaniach dowodzą, że konsumenci przy podejmowaniu decyzji o zakupie wołowiny kierują się m.in. ceną, a także jakością, wygodą użycia i wartościami odżywczymi. Kosicka-Gębska [2013] zauważa, że konsumenci mięsa wołowego zwracają przede wszystkim uwagę na trzy elementy: cenę, wygląd ogólny mięsa oraz jego barwę, a Mroczek [2010] podkreśla, że czynniki wpływające na konsumpcję mięsa wołowego obejmują: poziom dochodów społeczeństwa, ceny mięsa i preferencje konsumentów. To ostatnie stwierdzenie, wskazujące na ogólnie rozumiane dochody społeczeństwa jako determinantę poziomu spożycia mięsa, uzasadnia dodatkowo przyjęty cel rozprawy i odnosi się do stwierdzanych w literaturze przedmiotu prawidłowości mówiących o tym, że wzrost PKB w przeliczeniu na 1 mieszkańca powoduje odpowiednie zwiększenie spożycia mięsa i przetworów, nie powodując jednocześnie zmian w spożyciu produktów pochodzenia roślinnego [Gutkowska i Ozimek 2005].

Duże znaczenie ceny jako czynnika wyboru wiąże się z dochodami konsumentów. Sytuacja dochodowa gospodarstw domowych w bezpośredni sposób wpływa na poziom i strukturę wydatków konsumpcyjnych, określając możliwo- 


\section{4}

ści zaspokojenia ich potrzeb [Żelazna i in. 2002, Rudnicki 2004, Janoś-Kresło i Mróz 2006, Bywalec 2007, Woś i in. 2011, Gutkowska i in. 2012]. Wielkość dochodów pieniężnych wyznacza zakres swobody konsumpcyjnej, ograniczając lub zwiększając poziom zaspokojenia potrzeb.

$\mathrm{W}$ porównaniu $\mathrm{z}$ innymi rodzajami mięs to właśnie wołowina najbardziej zdrożała po akcesji Polski do UE, co było pochodną wysokiej ceny mięsa wołowego na rynku unijnym. Spowodowało to spadek popytu na ten rodzaj mięsa również w innych nowoprzyjętych do UE krajach [Štiková i in. 2009]. Cena skupu polskiej wołowiny wzrosła wówczas o $32 \%$ - z 2,5 do 3,3 zł/ $/ \mathrm{kg}$ [Biuletyn statystyczny 2005, 2006], przy czym tendencje wzrostu cen skupu utrzymują się nadal i w IV kwartale 2015 roku określono ten wzrost na 5,1\% w skali roku. Jednocześnie nastąpił wzrost cen detalicznych mięsa wołowego, które przykładowo na targowiskach wyniosły średnio $6,51 \mathrm{zł} / \mathrm{kg}$ i były wyższe w stosunku do 2014 roku o $2 \%$ [GUS 2015].

Spożycie wołowiny nigdy nie dominowało w strukturze konsumpcji mięsa w polskich gospodarstwach domowych, ale warto podkreślić, że o ile w 1990 roku stanowiło ono $23,83 \%$ udziału w całkowitym spożyciu mięsa, o tyle w 2015 roku spożycie wołowiny stanowiło zaledwie 2,09\% całkowitego spożycia mięsa przeciętnie na 1 osobę (tab. 1).

Pewnym wytłumaczeniem spadku spożycia wołowiny może być znacznie bardziej widoczna zmiana cen mięsa wołowego w stosunku do cen mięsa drobiowego i wieprzowiny. W latach 2004-2012 wzrost cen detalicznych wołowiny był większy niż cen wieprzowiny i mięsa drobiowego. Ceny rostbefu rosły w tempie $7,1 \%$ rocznie, a ceny detaliczne tuszki kurcząt o 4,7\% [Świetlik 2014].

Zachowania konsumentów wobec żywności, a w tym również mięsa i jego przetworów, uwarunkowane sąjednak nie tylko determinantami ekonomicznymi, ale też wieloma innymi czynnikami działającymi z różną siłą i często w różnych kierunkach, czego egzemplifikację prezentują dane w tabeli 2 przedstawiające stosunki korelacyjne $(\eta)$ według komponentów wariancyjnych.

$\mathrm{Z}$ analizy danych dotyczących poziomu spożycia mięsa wołowego wynika, że determinantą najsilniej oddziałującą na poziom spożycia mięsa wołowego w gospodarstwie domowym jest usytuowanie w strukturze województw i regionu kraju oraz sytuacja dochodowa. Największe spożycie wołowiny odnotowano w miejscowościach liczących 500 tysięcy i więcej mieszkańców, a najmniejsze na wsiach. Najwięcej wołowiny spożywają również gospodarstwa domowe, które składają się z małej liczby osób (rodziny dwu- i jednoosobowe). Konsumpcja w tych rodzinach w przeliczeniu na 1 osobę wynosiła średnio trzy razy więcej niż w gospodarstwach liczących pięć i więcej osób. Stosunkowo duże spożycie mięsa wołowego odnotowano również w gospodarstwach domowych małżeństw 
Tabela 1

Poziom spożycia mięsa w polskich gospodarstwach domowych w latach 1990-2015

\begin{tabular}{|c|c|c|c|c|}
\hline \multirow{4}{*}{ Lata } & \multicolumn{4}{|c|}{ Mięso łącznie z podrobami } \\
\hline & \multirow{2}{*}{ ogółem } & \multicolumn{3}{|c|}{ w tym mięso bez podrobów } \\
\hline & & wieprzowe & wołowe & drobiowe \\
\hline & \multicolumn{4}{|c|}{ kg/osobę/miesiąc } \\
\hline 1990 & 68,8 & 37,7 & 16,4 & 7,6 \\
\hline 1991 & 73,5 & 42,2 & 15,7 & 8,2 \\
\hline 1992 & 70,7 & 42,4 & 12,7 & 9,1 \\
\hline 1993 & 67,9 & 40,8 & 11,5 & 9,5 \\
\hline 1994 & 63,1 & 37,5 & 9,1 & 10,7 \\
\hline 1995 & 64,0 & 39,4 & 8,8 & 10,3 \\
\hline 1996 & 65,2 & 40,4 & 8,6 & 10,3 \\
\hline 1997 & 62,3 & 35,7 & 8,4 & 12,5 \\
\hline 1998 & 65,3 & 38,0 & 8,2 & 13,2 \\
\hline 1999 & 67,5 & 40,0 & 7,9 & 14,0 \\
\hline 2000 & 66,1 & 39,0 & 7,1 & 14,7 \\
\hline 2001 & 66,6 & 38,6 & 5,6 & 17,2 \\
\hline 2002 & 69,5 & 39,2 & 5,2 & 19,8 \\
\hline 2003 & 72,1 & 41,2 & 5,8 & 19,7 \\
\hline 2004 & 71,8 & 39,1 & 5,3 & 22,2 \\
\hline 2005 & 71,2 & 39,0 & 3,9 & 23,4 \\
\hline 2006 & 74,3 & 41,4 & 4,5 & 23,7 \\
\hline 2007 & 77,6 & 43,6 & 4,0 & 24,0 \\
\hline 2008 & 75,3 & 42,7 & 3,8 & 24,1 \\
\hline 2009 & 75,2 & 41,9 & 3,6 & 24,3 \\
\hline 2010 & 73,7 & 42,2 & 2,4 & 24,6 \\
\hline 2011 & 73,4 & 42,5 & 2,1 & 25,0 \\
\hline 2012 & 71,0 & 39,2 & 1,6 & 26,1 \\
\hline 2013 & 68,1 & 35,5 & 1,5 & 27,3 \\
\hline 2014 & 73,6 & 39,1 & 1,6 & 28,2 \\
\hline 2015 & 76,3 & 41,7 & 1,6 & 28,3 \\
\hline
\end{tabular}

Źródło: Opracowanie na podstawie [Rynek mięsa... 2016]. 
Tabela 2

Znaczenie poszczególnych determinant w kształtowaniu poziomu spożycia wołowiny i cielęciny w gospodarstwach domowych w Polsce w wybranych latach (stosunki korelacyjne $\eta$ )

\begin{tabular}{|l|c|c|c|c|c|}
\hline Zmienne & 2014 & 2010 & 2008 & 2000 & 1994 \\
\hline Województwo & 0,15 & 0,18 & 0,20 & 0,27 & 0,30 \\
\hline Region & 0,14 & 0,16 & 0,18 & 0,24 & 0,22 \\
\hline $\begin{array}{l}\text { Poziom dochodu w gospodarstwie } \\
\text { domowym (grupa decylowa) }\end{array}$ & 0,17 & 0,16 & 0,16 & 0,21 & 0,26 \\
\hline $\begin{array}{l}\text { Typ biologiczny w gospodarstwie } \\
\text { domowym }\end{array}$ & 0,14 & 0,12 & 0,14 & 0,16 & 0,24 \\
\hline Liczba osób w gospodarstwie domowym & 0,13 & 0,12 & 0,13 & 0,18 & 0,25 \\
\hline Zawód respondenta & 0,11 & 0,10 & 0,13 & 0,14 & - \\
\hline Główne źródło utrzymania & 0,12 & 0,11 & 0,12 & 0,17 & 0,24 \\
\hline Faza cyklu rozwoju rodziny & 0,12 & 0,10 & 0,12 & 0,16 & - \\
\hline Podgrupa społeczno-ekonomiczna & 0,11 & 0,11 & 0,12 & 0,16 & - \\
\hline Wiek respondenta (przedziały) & 0,10 & 0,10 & 0,11 & 0,13 & 0,18 \\
\hline Klasa miejscowości zamieszkania & 0,10 & 0,10 & 0,11 & 0,18 & 0,23 \\
\hline Wykształcenie respondenta & 0,09 & 0,08 & 0,10 & 0,11 & 0,15 \\
\hline Grupa społeczno-ekonomiczna & 0,08 & 0,09 & 0,10 & 0,13 & 0,20 \\
\hline Miesiąc badania & 0,04 & 0,03 & 0,04 & 0,05 & 0,03 \\
\hline Płeć respondenta & 0,01 & 0,02 & 0,03 & 0,02 & 0,05 \\
\hline
\end{tabular}

Źródło: Analiza wykonana przez dr. hab. Wacława Laskowskiego, prof. SGGW, na podstawie indywidualnych danych budżetów gospodarstw domowych pozyskanych z GUS.

bezdzietnych. Najczęściej były to osoby starsze, aktywne zawodowo, jak również młode małżeństwa bezdzietne [Gutkowska i in. 2012].

Poddając analizie poziom spożycia wołowiny i biorąc jednocześnie pod uwagę główne źródło utrzymania gospodarstwa domowego, najwięcej wołowiny spożywano w małych gospodarstwach domowych dysponujących relatywnie dużym dochodem rozporządzalnym przypadającym na 1 osobę. Rolnicy są grupą która spożywała najmniej mięsa wołowego, ale jednocześnie charakteryzowała się największym spożyciem mięsa ogółem, a zwłaszcza mięsa wieprzowego. Poddając analizie wpływ wykształcenia głowy gospodarstwa domowego na poziom spożycia wołowiny, stwierdzono, że w większości konsumentami mięsa wołowego są osoby z wykształceniem wyższym oraz średnim ogólnokształcącym.

Ostatnimi zmiennymi uwzględnionymi we wspomnianych badaniach były czynniki demograficzne, a wśród nich wiek oraz płeć głównego decydenta 
w gospodarstwie domowym. I tak, w większości konsumentami mięsa wołowego są osoby starsze (w wieku 60 lat i więcej), a czynnikiem mającym najmniejszy wpływ na poziom spożycia mięsa wołowego jest płeć. Miesiąc przeprowadzania badania nie wpłynął na poziom spożycia wołowiny, co zaskakuje, wziąwszy pod uwagę podkreślany przez uczestników pogłębionych dyskusji grupowych przeprowadzonych w ramach projektu „ProOptiBeef” ,uroczysty charakter wołowiny w przeciwieństwie do drobiu czy wieprzowiny", a zatem można by się spodziewać, że relatywnie więcej wołowiny konsumuje się przy okazji świąt, takich jak Boże Narodzenie czy Wielkanoc [Gutkowska i in. 2012].

\section{Uwarunkowania częstotliwości spożycia wołowiny w województwie świętokrzyskim i ich specyfika - analiza danych pierwotnych i ich dyskusja}

W świetle zgromadzonego materiału empirycznego stwierdzić można, że co piąty $(21 \%)$ badany konsument mieszkający w województwie świętokrzyskim deklarował, że spożywa mięso wołowe raz w tygodniu, przy czym czynnikami mającymi na to istotny wpływ były: poziom wykształcenia, liczba osób w wieku do 18. roku życia tworzących gospodarstwo domowe, wykonywany zawód.

Przeprowadzone badania własne potwierdziły współzależność między częstotliwością spożywania mięsa wołowego przez konsumentów a liczbą członków ich gospodarstw domowych w wieku do 18. roku życia $(\mathrm{p}=0,02)$. Niemal we wszystkich rodzajach „częstotliwości spożycia wołowiny” większość stanowili konsumenci reprezentujący gospodarstwa domowe bez dzieci do 18. roku życia (tab. 3).

Stwierdza się zatem, że spożycie mięsa wołowego zależy od liczby członków w wieku do 18. roku życia w gospodarstwach domowych, co potwierdza zauważone $\mathrm{w}$ innych badaniach (zarówno ilościowych, jak i jakościowych) prowadzonych w ramach projektu „ProOptiBeef” tendencje wskazujące na to, że dzieci (zwłaszcza najmłodsze) nie lubią wołowiny ze względu na trudności $\mathrm{w}$ jej pogryzieniu [niepublikowane raporty $\mathrm{z}$ badań konsumenckich realizowane w ramach zadania 1 projektu „ProOptiBeef”, Gutkowska i in. 2012].

Wśród konsumentów spożywających wołowinę raz w tygodniu i częściej dominowali pracownicy biurowi niższego szczebla (odpowiednio 40,16 oraz $14,96 \%$ ) oraz pracownicy umysłowi średniego szczebla (odpowiednio 45,27 oraz 7,41\%) - tabela 4, co potwierdzają też wyniki badań ogólnopolskich [Gutkowska i in. 2012, 2016, Kosicka-Gębska 2013]. 
Tabela 3

Współzależność między liczbą członków gospodarstwa domowego w wieku do 18. roku życia a częstotliwością spożycia wołowiny

\begin{tabular}{|c|c|c|c|c|c|c|c|c|c|c|c|c|c|c|}
\hline \multirow{3}{*}{$\begin{array}{l}\text { Częstotliwość } \\
\text { spożycia }\end{array}$} & \multicolumn{14}{|c|}{ Liczba członków gospodarstwa domowego w wieku do 18 lat } \\
\hline & \multicolumn{2}{|c|}{0} & \multicolumn{2}{|c|}{1} & \multicolumn{2}{|c|}{2} & \multicolumn{2}{|c|}{3} & \multicolumn{2}{|c|}{4} & \multicolumn{2}{|c|}{5} & \multicolumn{2}{|c|}{6} \\
\hline & $\mathrm{N}$ & $\%$ & $\mathrm{~N}$ & $\%$ & $\mathrm{~N}$ & $\%$ & $\mathrm{~N}$ & $\%$ & $\mathrm{~N}$ & $\%$ & $\mathrm{~N}$ & $\%$ & $\mathrm{~N}$ & $\%$ \\
\hline $\begin{array}{l}\text { Kilka razy } \\
\text { dziennie }\end{array}$ & 3 & 43 & 2 & 29 & 1 & 14 & 1 & 14 & 0 & 0 & 0 & 0 & 0 & 0 \\
\hline Codziennie & 3 & 60 & 1 & 20 & 0 & 0 & 0 & 0 & 1 & 20 & 0 & 0 & 0 & 0 \\
\hline $\begin{array}{l}\text { 6-4 razy } \\
\text { w tygodniu }\end{array}$ & 9 & 45 & 3 & 15 & 5 & 25 & 1 & 5 & 0 & 0 & 2 & 10 & 0 & 0 \\
\hline 3-2 razy & 42 & 72 & 7 & 12 & 7 & 12 & 1 & 2 & 1 & 2 & 0 & 0 & 0 & 0 \\
\hline Raz w tygodniu & 124 & 62 & 35 & 18 & 29 & 15 & 9 & 5 & 3 & 2 & 0 & 0 & 0 & 0 \\
\hline $\begin{array}{l}\text { 2-3 razy } \\
\text { w miesiącu }\end{array}$ & 116 & 64 & 34 & 19 & 24 & 13 & 6 & 3 & 1 & 1 & 0 & 0 & 0 & 0 \\
\hline Raz w miesiącu & 94 & 65 & 27 & 19 & 17 & 12 & 3 & 2 & 2 & 1 & 1 & 1 & 0 & 0 \\
\hline $\begin{array}{l}\text { Raz na } 2 \\
\text { miesiące }\end{array}$ & 56 & 70 & 10 & 13 & 9 & 11 & 3 & 4 & 0 & 0 & 2 & 3 & 0 & 0 \\
\hline Rzadziej & 99 & 62 & 28 & 18 & 19 & 12 & 8 & 5 & 5 & 3 & 0 & 0 & 1 & 1 \\
\hline Wcale & 81 & 68 & 17 & 14 & 14 & 12 & 6 & 5 & 1 & 1 & 1 & 1 & 0 & 0 \\
\hline
\end{tabular}

Źródło: Obliczenia własne na podstawie danych z projektu „ProOptibeef”.

\section{Tabela 4}

Struktura badanych ze względu na częstotliwość spożycia wołowiny w zależności od ich statusu zawodowego

\begin{tabular}{|c|c|c|c|c|c|c|}
\hline \multirow{4}{*}{$\begin{array}{l}\text { Częstotliwość } \\
\text { spożycia }\end{array}$} & \multicolumn{6}{|c|}{ Zawód } \\
\hline & \multicolumn{3}{|c|}{ pracownicy } & \multirow[b]{2}{*}{$\begin{array}{l}\text { uczeń/ } \\
\text { /student }\end{array}$} & \multirow[b]{2}{*}{$\begin{array}{l}\text { emeryci, } \\
\text { renciści, } \\
\text { bezrobotni }\end{array}$} & \multirow[b]{2}{*}{ inny } \\
\hline & $\begin{array}{l}\text { biurowi } \\
\text { niższego } \\
\text { szczebla, } \\
\text { rolnicy }\end{array}$ & $\begin{array}{l}\text { umysłowi } \\
\text { średniego } \\
\text { szczebla }\end{array}$ & $\begin{array}{c}\text { umysłowi wyż- } \\
\text { szego szczebla, } \\
\text { specjaliści, pry- } \\
\text { watni przedsię- } \\
\text { biorcy }\end{array}$ & & & \\
\hline & \multicolumn{6}{|c|}{$\%$} \\
\hline Wcale & 11,81 & 7,82 & 9,60 & 17,65 & 15,45 & 8,24 \\
\hline $\begin{array}{l}\text { Raz w miesiącu } \\
\text { i rzadziej }\end{array}$ & 33,07 & 39,51 & 42,40 & 40,44 & 34,15 & 48,24 \\
\hline $\begin{array}{l}\text { Raz w tygodniu, } \\
\text { 2-3 razy } \\
\text { w miesiącu }\end{array}$ & 40,16 & 45,27 & 40,00 & 31,99 & 41,46 & 37,65 \\
\hline $\begin{array}{l}\text { Przynajmniej } \\
\text { 2-3 razy } \\
\text { w tygodniu }\end{array}$ & 14,96 & 7,41 & 8,00 & 9,93 & 8,94 & 5,88 \\
\hline
\end{tabular}

Źródło: Obliczenia własne na podstawie danych z projektu „ProOptibeef”. 
Między badanymi grupami wyróżnionymi ze względu na przynależność do określonej grupy zawodowej zaobserwowano istotną różnicę w rozkładzie badanej zmiennej ( $\mathrm{p}<0,05)$, wskazująca na to, że:

- badani będący pracownikami biurowymi niższego szczebla i rolnicy częściej niż pozostałe osoby spożywali wołowinę przynajmniej 2-3 razy w tygodniu,

- uczniowie/studenci oraz emeryci, renciści i bezrobotni częściej niż pozostałe osoby deklarowali, że wcale nie jedzą wołowiny,

- osoby wykonujące inne zawody częściej niż pozostali respondenci spożywały wołowinę raz w miesiącu i rzadziej.

W kontekście uzyskanych wyników z badań własnych można wnioskować, że wykształcenie członków rodziny, liczba dzieci w wieku do 18. roku życia w gospodarstwie domowym i wykonywane przez domowników zawody są zmiennymi, które w statystycznie istotny sposób wpływały na częstotliwość spożycia wołowiny wśród badanych konsumentów z województwa świętokrzyskiego. Wiek, płeć oraz uzyskiwany poziom dochodu nie wpływały statystycznie istotnie na częstotliwość spożycia wołowiny (tab. 5 i 6).

Tabela 5

Współzależność między płcią, wykształceniem i dochodem miesięcznym konsumentów a częstotliwościa spożycia mięsa wołowego

\begin{tabular}{|c|c|c|c|c|c|c|c|c|c|c|c|}
\hline \multirow{2}{*}{\multicolumn{2}{|c|}{$\begin{array}{c}\text { Zmienne } \\
\text { socjodemograficzne }\end{array}$}} & \multicolumn{2}{|c|}{$\begin{array}{c}\text { Kilka razy } \\
\text { dziennie }\end{array}$} & \multicolumn{2}{|c|}{ Codziennie } & \multicolumn{2}{|c|}{$\begin{array}{c}\text { 6-4 razy } \\
\text { w tygo- } \\
\text { dniu }\end{array}$} & \multicolumn{2}{|c|}{ 3-2 razy } & \multicolumn{2}{|c|}{$\begin{array}{c}\text { Raz } \\
\text { w tygo- } \\
\text { dniu }\end{array}$} \\
\hline & & $\mathrm{N}$ & $\%$ & $\mathrm{~N}$ & $\%$ & $\mathrm{~N}$ & $\%$ & $\mathrm{~N}$ & $\%$ & $\mathrm{~N}$ & $\%$ \\
\hline 1 & 2 & 3 & 4 & 5 & 6 & 7 & 8 & 9 & 10 & 11 & 12 \\
\hline \multirow{2}{*}{$\frac{0}{\frac{0}{L}}$} & kobiety & 3 & 43 & 2 & 40 & 8 & 40 & 15 & 26 & 55 & 28 \\
\hline & mężczyźni & 4 & 57 & 3 & 60 & 12 & 60 & 42 & 74 & 144 & 72 \\
\hline \multirow{10}{*}{$\begin{array}{l}\frac{\pi}{\frac{\pi}{0}} \\
\frac{\pi}{6} \\
\frac{1}{0} \\
\frac{0}{3}\end{array}$} & $<19$ & 1 & 20 & 0 & 0 & 4 & 25 & & 13 & 54 & 30 \\
\hline & $19-25$ & 0 & 0 & 0 & 0 & 1 & 6 & 9 & 18 & 14 & 8 \\
\hline & $26-30$ & 0 & 0 & 1 & 20 & 4 & 25 & 3 & 6 & 36 & 20 \\
\hline & $31-35$ & 2 & 40 & 2 & 40 & 3 & 19 & 5 & 10 & 24 & 13 \\
\hline & $36-40$ & 2 & 40 & 0 & 0 & 2 & 13 & 9 & 18 & 20 & 11 \\
\hline & $41-45$ & 0 & 0 & 1 & 20 & 0 & 0 & 5 & 10 & 15 & 8 \\
\hline & $46-50$ & 0 & 0 & 0 & 0 & 1 & 6 & 4 & 8 & 11 & 6 \\
\hline & $51-55$ & 0 & 0 & 1 & 20 & 0 & 0 & 1 & 2 & 5 & 3 \\
\hline & $56-60$ & 0 & 0 & 0 & 0 & 0 & 0 & 0 & 0 & 1 & 1 \\
\hline & $61-65$ & 0 & 0 & 0 & 0 & 1 & 6 & 1 & 2 & 3 & 2 \\
\hline \multirow{5}{*}{ 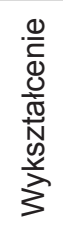 } & podstawowe & 0 & 0 & 1 & 20 & 5 & 25 & 0 & 0 & 3 & 2 \\
\hline & gimnazjalne & 1 & 14 & 0 & 0 & 3 & 15 & 4 & 7 & 7 & 4 \\
\hline & zasadnicze & 1 & 14 & 1 & 20 & 1 & 5 & 4 & 7 & 11 & 6 \\
\hline & średnie & 2 & 29 & 3 & 60 & 5 & 25 & 25 & 43 & 82 & 41 \\
\hline & wyższe & 3 & 43 & 0 & 0 & 6 & 30 & 25 & 43 & 97 & 49 \\
\hline
\end{tabular}


Tabela $5 \mathrm{~cd}$.

\begin{tabular}{|c|c|c|c|c|c|c|c|c|c|c|c|}
\hline 1 & 2 & 3 & 4 & 5 & 6 & 7 & 8 & 9 & 10 & 11 & 12 \\
\hline \multirow{5}{*}{ 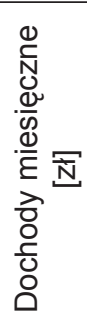 } & $<1000$ & 0 & 0 & 0 & 0 & 1 & 5 & 8 & 15 & 17 & 9 \\
\hline & $1001-1500$ & 0 & 0 & 1 & 20 & 4 & 20 & 8 & 15 & 30 & 15 \\
\hline & $1501-3000$ & 4 & 57 & 2 & 40 & 4 & 20 & 19 & 35 & 71 & 36 \\
\hline & $3001-5000$ & 1 & 14 & 1 & 20 & 9 & 45 & 14 & 25 & 61 & 31 \\
\hline & $>5000$ & 2 & 29 & 1 & 20 & 2 & 10 & 6 & 11 & 17 & 9 \\
\hline
\end{tabular}

Źródło: Obliczenia własne na podstawie danych z projektu „ProOptibeef”.

Tabela 6

Współzależność między płcią, wykształceniem i dochodem miesięcznym konsumentów a częstotliwością spożywanego mięsa wołowego; kontynuacja tabeli 5

\begin{tabular}{|c|c|c|c|c|c|c|c|c|c|c|c|c|}
\hline \multirow{2}{*}{\multicolumn{2}{|c|}{$\begin{array}{l}\text { Zmienne } \\
\text { socjodemo- } \\
\text { graficzne }\end{array}$}} & \multicolumn{2}{|c|}{$\begin{array}{c}2-3 \text { razy } \\
\text { w miesiącu }\end{array}$} & \multicolumn{2}{|c|}{$\begin{array}{c}1 \mathrm{raz} \\
\text { miesiącu }\end{array}$} & \multicolumn{2}{|c|}{$\begin{array}{c}\text { Raz na } \\
2 \text { miesiące }\end{array}$} & \multicolumn{2}{|c|}{ Rzadziej } & \multicolumn{2}{|c|}{ Wcale } & \multirow[t]{2}{*}{$p$} \\
\hline & & $\mathrm{N}$ & $\%$ & $\mathrm{~N}$ & $\%$ & $\mathrm{~N}$ & $\%$ & $\mathrm{~N}$ & $\%$ & $\mathrm{~N}$ & $\%$ & \\
\hline & 1 & 2 & 3 & 4 & 5 & 6 & 7 & 8 & 9 & 10 & 11 & 12 \\
\hline \multirow{2}{*}{ 过 } & kobiety & 42 & 23 & 40 & 28 & 19 & 24 & 46 & 29 & 24 & 20 & \multirow[b]{2}{*}{0,552} \\
\hline & $\begin{array}{l}\text { męż- } \\
\text { czyźni }\end{array}$ & 138 & 77 & 102 & 72 & 61 & 76 & 113 & 71 & 95 & 80 & \\
\hline \multirow{10}{*}{$\begin{array}{l}\frac{\pi}{\frac{\pi}{\pi}} \\
\frac{\pi}{0} \\
\frac{x}{0} \\
\frac{1}{3}\end{array}$} & <niż 19 & 38 & 23 & 30 & 24 & 19 & 27 & 43 & 31 & 34 & 34 & \multirow{10}{*}{0,585} \\
\hline & 19-25 & 16 & 10 & 12 & 10 & 14 & 20 & 14 & 10 & 11 & 11 & \\
\hline & $26-30$ & 18 & 11 & 20 & 16 & 4 & 6 & 15 & 11 & 18 & 18 & \\
\hline & $31-35$ & 20 & 12 & 18 & 14 & 9 & 13 & 22 & 16 & 9 & 9 & \\
\hline & $36-40$ & 23 & 14 & 16 & 13 & 12 & 17 & 15 & 11 & 9 & 9 & \\
\hline & $41-45$ & 19 & 11 & 13 & 10 & 6 & 9 & 14 & 10 & 8 & 8 & \\
\hline & $46-50$ & 21 & 13 & 9 & 7 & 2 & 3 & 10 & 7 & 7 & 7 & \\
\hline & $51-55$ & 6 & 4 & 4 & 3 & 3 & 4 & 4 & 3 & 3 & 3 & \\
\hline & $56-60$ & 4 & 2 & 2 & 2 & 1 & 1 & 1 & 1 & 1 & 1 & \\
\hline & $61-65$ & 2 & 1 & 2 & 2 & 0 & 0 & 2 & 1 & 1 & 1 & \\
\hline \multirow{5}{*}{ 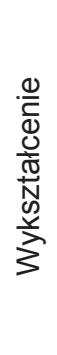 } & $\begin{array}{c}\text { podsta- } \\
\text { wowe }\end{array}$ & 2 & 1 & 2 & 1 & 2 & 3 & 4 & 3 & 2 & 2 & \multirow{5}{*}{0,000} \\
\hline & $\begin{array}{l}\text { gimna- } \\
\text { zjalne }\end{array}$ & 10 & 6 & 7 & 5 & 4 & 5 & 8 & 5 & 14 & 12 & \\
\hline & $\begin{array}{l}\text { zasad- } \\
\text { nicze }\end{array}$ & 7 & 4 & 8 & 6 & 2 & 3 & 14 & 9 & 11 & 9 & \\
\hline & średnie & 79 & 44 & 56 & 39 & 32 & 40 & 71 & 44 & 52 & 43 & \\
\hline & wyższe & 83 & 46 & 71 & 49 & 40 & 50 & 63 & 39 & 41 & 34 & \\
\hline
\end{tabular}


Tabela $6 \mathrm{~cd}$.

\begin{tabular}{|c|c|c|c|c|c|c|c|c|c|c|c|c|}
\hline 1 & 2 & 3 & 4 & 5 & 6 & 7 & 8 & 9 & 10 & 11 & 12 & 13 \\
\hline \multirow{5}{*}{ 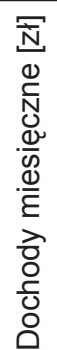 } & $<1000$ & 16 & 9 & 12 & 8 & 12 & 15 & 13 & 8 & 10 & 9 & \multirow{5}{*}{0,190} \\
\hline & $\begin{array}{c}1001- \\
1500\end{array}$ & 38 & 21 & 21 & 15 & 10 & 13 & 26 & 16 & 23 & 20 & \\
\hline & $\begin{array}{c}1501- \\
3000\end{array}$ & 70 & 39 & 58 & 41 & 30 & 38 & 79 & 50 & 57 & 49 & \\
\hline & $\begin{array}{c}3001- \\
5000\end{array}$ & 35 & 20 & 37 & 26 & 17 & 22 & 29 & 18 & 19 & 16 & \\
\hline & $>5000$ & 19 & 11 & 15 & 10 & 10 & 13 & 12 & 8 & 8 & 7 & \\
\hline
\end{tabular}

Źródło: Obliczenia własne na podstawie danych z projektu „ProOptibeef”.

Badanie ogólnopolskie Moskalik i Wielickiej [2006] potwierdziło, że głównie mężczyźni spożywają relatywnie dużo wołowiny. W większości jednak osoby te, podobnie jak konsumenci województwa świętokrzyskiego, mają wykształcenie średnie $\mathrm{i}$ wyższe oraz pochodzą z dużych miast. Wyniki te znalazły potwierdzenie w badaniu Piekut [2006] oraz w badaniach zrealizowanych w projekcie „ProOptiBeef” [Gutkowska i in. 2012].

Grupą wiekową, z której osoby częściej niż inne kupują mięso wołowe w województwie świętokrzyskim (raz w tygodniu), są osoby w wieku 26-30 lat (30\%) oraz w wieku powyżej 61 lat (25\%). Badania własne potwierdzają tendencję występującą w całej Polsce dotyczącą wieku konsumentów mięsa wołowego [Gutkowska i in. 2012, Kosicka-Gębska 2013].

Poddając analizie odpowiedzi respondentów z terenu województwa świętokrzyskiego, można zauważyć, że wśród konsumentów spożywających z większą częstotliwością wołowinę dominują konsumenci zarabiający miesięcznie od 1501 do 3000 zł, a wraz ze wzrostem częstotliwości spożycia tego rodzaju mięsa wzrastał udział w poszczególnych grupach konsumentów zarabiających ponad $3000 \mathrm{zł} /$ miesiąc.

Zwrócono też uwagę w badaniach własnych na to, czy respondenci są zadowoleni z ilości konsumowanej wołowiny. Blisko połowa z nich (48\%) uważała, że spożywa zdecydowanie za mało mięsa wołowego, przy czym wśród tej grupy respondentów dominowali konsumenci z wykształceniem wyższym, jak również mężczyźni, chociaż ta ostatnia zależność nie była statystycznie istotna (tab. 7).

Generalnie uważa się, że polscy konsumenci spożywają niewiele mięsa wołowego $\mathrm{w}$ porównaniu $\mathrm{z}$ innymi gatunkami mięsa. Tak też uważają konsumenci z województwa świętokrzyskiego, którzy w większości $(46,2 \%)$ deklarują, że spożywają zdecydowanie za mało wołowiny; co czwarty $(23,5 \%)$ badany ocenił, że spożywa odpowiednią ilość tego gatunku mięsa, a jedynie $2 \%$ badanych uważało, że spożywa jej za dużo. Tak duży odsetek badanych uznających poziom 
Tabela 7

Zależność między płcią i wykształceniem a oceną ilości spożywanego mięsa wołowego

\begin{tabular}{|c|c|c|c|c|c|c|c|c|c|c|}
\hline \multirow{2}{*}{\multicolumn{2}{|c|}{$\begin{array}{c}\text { Zmienne } \\
\text { socjodemograficzne }\end{array}$}} & \multicolumn{2}{|c|}{$\begin{array}{l}\text { Zdecydowa- } \\
\text { nie za mało }\end{array}$} & \multicolumn{2}{|c|}{$\begin{array}{l}\text { Odpowiednia } \\
\text { ilość }\end{array}$} & \multicolumn{2}{|c|}{ Za dużo } & \multicolumn{2}{|c|}{$\begin{array}{c}\text { Trudno } \\
\text { powiedzieć }\end{array}$} & \multirow[t]{2}{*}{$p$} \\
\hline & & $\mathrm{N}$ & $\%$ & $\mathrm{~N}$ & $\%$ & $\mathrm{~N}$ & $\%$ & $\mathrm{~N}$ & $\%$ & \\
\hline \multirow{2}{*}{$\frac{0}{\frac{0}{0}}$} & kobiety & 102 & 40 & 71 & 28 & 9 & 4 & 75 & 29 & \multirow{2}{*}{0,021} \\
\hline & mężczyźni & 337 & 49 & 153 & 22 & 10 & 1 & 193 & 28 & \\
\hline \multirow{5}{*}{ 龸 } & podstawowe & 11 & 55 & 2 & 10 & 0 & 0 & 7 & 35 & \multirow{5}{*}{0,264} \\
\hline & gimnazjalne & 18 & 31 & 18 & 31 & 2 & 3 & 21 & 36 & \\
\hline & zasadnicze & 28 & 47 & 10 & 17 & 3 & 5 & 18 & 31 & \\
\hline & średnie & 183 & 45 & 101 & 25 & 8 & 2 & 111 & 28 & \\
\hline & wyższe & 202 & 48 & 97 & 23 & 6 & 1 & 112 & 27 & \\
\hline
\end{tabular}

Źródło: Obliczenia własne na podstawie danych z projektu „ProOptibeef”.

spożycia wołowiny za zdecydowanie za niski, może wynikać z faktu, że od wielu lat obserwuje się stosunkowo wysoki poziom spożycia wołowiny wśród mieszkańców województwa świętokrzyskiego [Gutkowska i in. 2012], a w związku $\mathrm{z}$ tym konsumenci zamieszkali w tym rejonie kraju nawiązują do czasów, gdy cena wołowiny nie limitowała jej konsumpcji.

Wśród konsumentów w układzie ogólnoświatowym, za grupę, która spożywa stosunkowo dużą ilość mięsa wołowego, uznaje się Amerykanów. Badania pokazały, że są oni zadowoleni z obecnego poziomu konsumpcji tego gatunku mięsa, a prowadzona od ponad 30 lat polityka żywnościowa spowodowała, że amerykańscy konsumenci ograniczają spożycie wołowiny [O’Neil i in. 2011].

Badania dotyczące konsumpcji wołowiny w innych krajach dowiodły, że w rosyjskim społeczeństwie mężczyźni preferują spożywanie mięsa czerwonego w większych ilościach, co jest typowe również dla innych krajów, a zjawisko to tłumaczone jest tym, że kobiety bardziej dbają o niskokaloryczne posiłki, w związku z czym częściej rezygnują z posiłków mięsnych. Wzrost poziomu dochodów w danym społeczeństwie implikuje zwiększenie ilości spożywanego mięsa wołowego. W grupie o zwiększonej ilości spożycia mięsa czerwonego są także osoby w wieku 19-30 oraz 51-60 lat, pochodzące z dużych miast oraz legitymujące się średnim oraz wyższym wykształceniem, a także osoby uzyskujące większe niż przeciętne dochody [Honkanen 2010]. Jak wykazują różnorodne badania, Polacy w porównaniu z konsumentami z innych krajów spożywają małe ilości wołowiny [Wyness i in. 2011, McNeill 2012].

Porównując wyniki badań prowadzonych w Polsce z tymi z innych krajów byłego bloku wschodniego należy wskazać, że Czesi stosunkowo rzadko kupują jak też rzadko spożywają mięso wołowe. Niespełna połowa (47\%) badanych 
osób przyznała, że zakupu tego typu dokonuje rzadziej niż raz w tygodniu, a 41\% z nich, że w ogóle nie kupuje wołowiny [Kubickova i Šerhantova 2005].

Spadku spożycia mięsa wołowego w Polsce dowiodły też badania przeprowadzone przez CBOS, z których wynika, że ponad połowa biorących w nich udział osób deklarowała, że jada mniej wołowiny niż 15 lat temu, przy czym co ósmy $(13 \%)$ w ogóle przestał ją jeść [CBOS 2005].

\section{Podsumowanie}

Przeprowadzone analizy danych wtórnych oraz informacji pierwotnych potwierdziły słuszność przyjętej hipotezy, bowiem cechy socjodemograficzne charakteryzujące gospodarstwa domowe wykazujące skrajne częstotliwości spożycia mięsa wołowego, zarówno w skali ogólnopolskiej, jak i województwa świętokrzyskiego wykazują znaczne podobieństwo. Tym samym potwierdza się, że niezależnie od sytuacji makroekonomicznej regionu na poziom spożycia wołowiny w lokalnych gospodarstwach domowych wpływają statystycznie istotnie zmienne, takie jak: wiek domowników, wykształcenie, wykonywane przez nich zawody, liczba dzieci w wieku do 18 lat na utrzymaniu. Nie zaobserwowano zaś, aby w gospodarstwach domowych w województwie o niekorzystnych wskaźnikach makroekonomicznych (do jakich należy województwo świętokrzyskie) istniał statystycznie istotny wpływ sytuacji dochodowej gospodarstwa domowego na poziom, a więc i częstotliwość spożycia wołowiny. W skali ogólnopolskiej zaobserwowano zależność wskazującą na to, że im większy dochód gospodarstwa, tym większe spożycie wołowiny. Nie wystapiła ona jednak w badaniach przeprowadzonych w województwie świętokrzyskim, co można wyjaśnić istnieniem żywszej tradycji spożycia wołowiny w tym rejonie kraju. Takie przypuszczenie potwierdzają również przedstawione $\mathrm{w}$ artykule spostrzeżenia dotyczące większego niż stwierdzono średnio w Polsce odsetka konsumentów niezadowolonych $\mathrm{z}$ aktualnego poziomu spożycia wołowiny $\mathrm{w}$ ich gospodarstwach domowych.

\section{Literatura}

Biuletyn statystyczny 2005, GUS, Warszawa 2006.

BYWALEC Cz., 2007: Konsumpcja $w$ teorii i praktyce gospodarowania, PWN, Warszawa. CBOS, 2005: Upodobania kulinarne, nawyki żywieniowe i zachowania konsumenckie Polaków, Komunikat z badań, http://www.cbos.pl/SPISKOM.POL/2005/K_173_05.PDF. 
EVANS A., 2009: The Feeding of the Nine Billion. Global Food Security for the 21st Century, Chatham House Report 7, London, http://citeseerx.ist.psu.edu/viewdoc/download?doi=10.1.1.170.1355\&rep=rep1\&type $=$ pdf.

GUTKOWSKA K., KOSICKA-GĘBSKA M., BATÓG A., 2012: Zachowania polskich konsumentów wobec wołowiny w świetle wyników badań CATI, [w:] K. Gutkowska (red.), Możliwości rozwoju rynku wołowiny w Polsce w kontekście zachowań konsumentów wobec mięsa - odniesienia międzynarodowe, Wydawnictwo SGGW, Warszawa, 54-67.

GUTKOWSKA K., KOSICKA-GĘBSKA M., SAJDAKOWSKA M., ŻAKOWSKA-BIEMANS S., GUZEK D., 2016: Poziom i uwarunkowania spożycia wołowiny $w$ polskich gospodarstwach domowych na tle tendencji światowych, [w:] J. Wierzbicki, A. Wierzbicka, K. Lendzion, A. Wierzbicka (red.), Standardy mięsa wołowego, wydanie rozszerzone, Wydawnictwo PZPBM, Warszawa, 2-26.

GUTKOWSKA K., OZIMEK I., 2005: Wybrane aspekty zachowań konsumentów na rynku żywności - kryteria zróżnicowania, Wydawnictwo SGGW, Warszawa.

GUTKOWSKA K., OZIMEK I., 2008: Zachowania młodych konsumentów na rynku żywności-wybrane aspekty, Wydawnictwo SGGW, Warszawa.

HONKANEN P., 2010: Food preference based segments in Russia, Food Quality and Preference 21(1), 65-74.

JANOŚ-KRESŁO M., MRÓZ B. (red.), 2006: Konsument i konsumpcja we współczesnej gospodarce, Oficyna Wydawnicza SGH, Warszawa.

KOSICKA-GĘBSKA M., 2013: Zachowania polskich konsumentów na rynku wołowiny, Wydawnictwo SGGW, Warszawa.

KUBICKOVA L., ŠERHANTOVA V., 2005: Analysis of Changes in Meat and Meat Products Consumption in the Czech Republic in the Past Ten Years, Agricultural Economics of Czech 51(9), 395-401.

McNEILL S.H., HARRIS K.B., FIELD T.G., VAN ELSWYK M.E., 2012: The evolution of lean beef: Identifying lean beef in today's U.S. marketplace, Meat Science 90, 1-8.

Meat Atlas. Facts and figures about the animals we eat, 2014: Heinrich Böll Foundation, https:// www.foeeurope.org/sites/default/files/publications/foee_hbf_meatatlas_jan2014.pdf.

MROCZEK R., 2010: Wyzwania i bariery produkcji mięsa w Polsce, Przemysł Spożywczy 64(3), 2-6.

MOSKALIK B., WIELICKA A., 2006: Konsumpcja mięsa i produktów mięsnych, Rynek Wewnętrzny, czerwiec, 238-234.

Niepublikowane raporty z badań konsumenckich realizowane w zadaniu $n r$ 1. „Analiza popytu na mięso wołowe w Polsce" w latach 2013-2014 w ramach projektu ,ProOptiBeef”.

O’NEIL C.E., ZANOVEC M., KEAST D.R., FULGONI V.L., NICKLAS T.A., 2011: Nutrient contribution of total and lean beef in diets of US children and adolescennts: National Health and Nutrition Examination Survey 1999-2004, Meat Science 87, 250-256.

Opracowanie sygnalne GUS 2015, Warszawa 2016.

PERENC J., 2010: Ekonomiczne determinanty zachowań współczesnych nabywców, Zeszyty Naukowe Uniwersytet Szczeciński 609, Problemy Zarządzania, Finansów i Marketingu 16, 289-308.

PIEKUT M., 2008: Spożycie mięsa i przetworów mięsnych $w$ gospodarstwach domowych, Gospodarka Mięsna 11, 14-17. 
RUDNICKI L., 2004: Zachowania rynkowe nabywców. Mechanizmy i uwarunkowania, Wydawnictwo AE w Krakowie, Kraków.

Rocznik statystyczny rolnictwa, GUS, Warszawa 2010, 2014, 2015, 2016.

Rynek mięsa - stan i perspektywy. Analizy rynkowe, IERiGŻ-PIB, ARR, MRiRW 50/2016.

ŠTIKOVÁ O., SEKAVOVÁ H., MRHÁLKOVÁ I., 2009: Vliv socio-ekonomických faktorů na spotřebu potravin, Ústav zemědělské ekonomiky a informací, Praha.

ŚWIATOWY G., 2006: Zachowania konsumentów, PWE, Warszawa.

ŚWIETLIK K., 2014: Dylematy rozwoju konsumpcji żywności w warunkach niestabilnej koniunktury, Konsumpcja i Rozwój 3(8), 3-15.

WOŚ J., RACHOCKA J., KASPEREK-HOPPE M., 2011: Zachowania konsumentów - teoria i praktyka, Wydawnictwo UE w Poznaniu, Poznań.

WYNESS L., WEICHSELBAUM E., O'CONNOR A., WILLIAMS E.B., BENELAM B., RILEY H., STANNER S., 2011: Red meat in the diet: an update, Nutrition Bulletin 36, 34-77.

ŻELAZNA K., KOWALCZUK I., MIKUTA B., 2002: Ekonomika konsumpcji - elementy teorii, Wydawnictwo SGGW, Warszawa.

\section{Abstrakt}

Celem podjętych badań było określenie specyfiki zachowań konsumentów wołowiny z województwa świętokrzyskiego zarówno w odniesieniu do częstotliwości, wielkości i powodów jej spożywania, jak i innych aspektów zachowań żywieniowych konsumentów zamieszkujących ten region kraju. Analiza danych wtórnych oraz badań ankietowych przeprowadzonych wśród mieszkańców województwa świętokrzyskiego w okresie od lutego 2013 do września 2014 roku potwierdziła, że niezależnie od sytuacji makroekonomicznej regionu na poziom spożycia wołowiny w lokalnych gospodarstwach domowych wpływają statystycznie istotnie zmienne, takie jak: wiek członków rodziny, ich wykształcenie, wykonywane przez nich zawody, liczba dzieci w wieku do 18 lat na utrzymaniu. Nie zauważa się zaś, aby w gospodarstwach domowych w województwie o niekorzystnych wskaźnikach makroekonomicznych, istniał statystycznie istotny wpływ dochodu gospodarstwa na poziom, a więc i częstotliwość spożycia wołowiny. W skali ogólnopolskiej zaobserwowano zależność, że im większy dochód gospodarstwa, tym większe spożycie wołowiny. Nie udokumentowano tej zależności w badaniach przeprowadzonych w województwie świętokrzyskim, co można uzasadnić istnieniem w tym rejonie kraju żywszej tradycji konsumpcji wołowiny. Takie przypuszczenie potwierdzają również przedstawione $\mathrm{w}$ artykule spostrzeżenia dotyczące większego, niż stwierdzono średnio w Polsce odsetka konsumentów niezadowolonych z aktualnego poziomu spożycia wołowiny w ich gospodarstwach domowych. 
Słowa kluczowe: konsument, spożycie wołowiny, niekorzystne wskaźniki makroekonomiczne, województwo świętokrzyskie

\title{
Selected aspects of beef consumption in the region with unfavourable macroeconomic indicators
}

\begin{abstract}
The purpose of the study was to determine the specific behaviour of consumers living in the Świętokrzyskie voivodeship towards beef, both in terms of frequency, the size and the reasons of its consumption and other aspects of the consumers' nutrition behaviour. The analysis of secondary data and the results of survey conducted in the period between February of 2013 and September of 2014 confirmed that irrespective of the macroeconomic situation of the region, the level of beef consumption in the households located in this region is influenced by statistically significant variables, such as: age, education, occupation, number of children under 18 years of age. However, it is not noticed that households in the voivodeship with unfavourable macroeconomic indicators had a statistically significant relationship of beef consumption frequency with the household income situation. Nevertheless, there is a nationwide presence of such correlation, indicating that the higher the household income is, the higher the consumption of beef. The lack of this relationship documented in studies conducted in the Świętokrzyskie voivodeship can be explained in this region of the country by the more clear tradition of beef eating. This assumption is also confirmed by the observations in the study referring to the higher than the average percentage of dissatisfied consumers with the current level of beef consumption in their households.
\end{abstract}

Key words: consumer, beef consumption, unfavourable macroeconomic indicators, Świętokrzyskie voivodeship 